\title{
Toward the development of sustainable ecotourism in Italian national parks of the Apennines: insights from hiking guides
}

\author{
Stefano Poponi $^{1}$, Jordan Palli $^{2}$, Sonia Ferrari $^{3}$, Goffredo Filibeck $^{2}$, Tai G. W. Forte $^{4}$, Cinzia Franceschini $^{2}$, Alessandro Ruggieri $^{5}$ and $^{2}$
} Gianluca Piovesan $^{2}$

\begin{abstract}
National parks in mountain areas are biodiversity hotspots in which implementing the sustainability goals of Agenda 2030 is particularly urgent. Ecotourism provides an opportunity to convey bio-ecological and economic sustainability principles to the public, focusing on nature conservation and a reduction of the negative impacts of tourism. We investigated four national parks in the Apennines, Italy using the insights of hiking guides with park accreditation to assess sustainability issues. Multivariate analyses of questionnaires revealed that most of the interviewed hiking guides across the Apennines were sensitive toward the theme of sustainability. Limiting the ecological footprint of tourism was identified as the main challenge. Interesting feedback on management issues was given by hiking guides, indicating innovations such as food, waste-disposal management, accommodation, and transport as critical areas with the potential to impact sustainable development. Certification schemes were also recognized as an important tool with which to encourage ecologically responsible tourism. Hiking guides themselves revealed an interest in improving national parks' scientific communication and the provision of lifelong learning initiatives regarding old-growth forests and nature conservation. Overall, the research highlights the key role of hiking guides as an effective means of conveying conservation messaging to ecotourists, while also encouraging sustainable development and the adoption of agro-environmental measures on the part of local communities. Hiking guides could, therefore, contribute toward both improving cultural awareness of conservation issues and encouraging local, low-impact economic practices.
\end{abstract}

Key Words: conservation messaging; ecotourism; hiking guides; national parks; old-growth forest; sustainability; UNESCO

\section{INTRODUCTION}

\section{Ecotourism and sustainability}

Sustainable development is defined as a "...development that meets the needs of the present without compromising the ability of future generations to meet their own needs" (WCED 1987).

One of the greatest challenges of sustainable development is to protect biodiversity on a planet on which human pressure on the environment is constantly increasing (Wilson 2016). Protected areas are essential if long-term conservation goals are to be achieved (Dudley 2008; see also the UN 2030 Agenda for Sustainable Development, goal 15; UN 2015). Such areas include a variety of sites in which a wide range of different management approaches can be found, from strict nature reserves and wilderness areas with restricted or forbidden entrance (International Union for Conservation of Nature $1 \mathrm{a}$ and $\mathrm{b}$ categories) to National Parks, which emphasize protecting natural biodiversity and ecological processes, but also welcome visitors and promote environmental education, low-impact recreation, and marginal local economies (Dudley 2008).

In protected areas, various forms of sustainable tourism are allowed. Sustainable tourism aims to promote the development of an area while ensuring its resources are not depleted for future generations by minimizing negative environmental impacts, maximizing positive socioeconomic effects and allowing for the even distribution of its benefits among the main stakeholders (Spangenberg 2002, Miller 2001, Mowforth and Munt 2003, Weaver 2006, 2010, Stoddard et al. 2012, Tyrrell et al. 2013,
Molina-Azorín and Font 2016, Pérez-Calderón 2020). Environment, culture and society, and economy represent the three main dimensions of sustainability in tourism, the so-called "triple bottom line"65 (Farrell 1992, Elkington 1997, 1998, 2004, Boley and Uysal 2014). The environmental dimension refers to the nature conservation and sustainable resources use of the area (Naughton-Treves et al. 2005, DeFries et al. 2007, MondéjarJiménez et al. 2012, Job et al. 2017). The social-cultural aspect encompasses various aspects pertaining to the local communities, such as civic pride, the revival of local culture, environmental education, welfare, reinforcement of social cohesion, tourist satisfaction, and the optimization of the relationship between hosts and guests (Bartelmus 1986, Pearce et al. 1990, Clarke 1997, Swarbrooke 1999, Spangenberg 2002, Jamal and Stronza 2009, Liang and Hui 2016, Jeon et al. 2016). Finally, the economic dimension includes the maximization of incomes and the development of local enterprises, which promote employment and sales of the area's products and services (Choi and Sirakaya 2006, Roberts and Tribe 2008, Garay and Font 2012).

Ecotourism is a sector of tourism consisting of people "traveling to relatively undisturbed or uncontaminated natural areas with the specific objective of studying, admiring and enjoying the scenery and its wild plants and animals as well as any existing cultural manifestations (both past and present) found in these areas" (Boo 1990:XIV). The experience combines education, recreation, and often adventure (Laarman and Durst 1987, Dangi and Gribb 2018). Over the years, ecotourism holidays have grown faster than conventional trips and it seems that this trend will

${ }^{1}$ Faculty of Economics, Niccolò Cusano University, Rome, Italy, ${ }^{2}$ Department of Agriculture and Forest Sciences (DAFNE), University of Tuscia, Viterbo, Italy, ${ }^{3}$ Department of Business and Legal Sciences (DiScAG), University of Calabria, Rende, Italy, ${ }^{4}$ Department of Chemistry, Life Sciences and Environmental Sustainability (SCVSA), University of Parma, Parma, Italy, Department of Economy, Engineering, Society and Business (DEIM), University of Tuscia, Viterbo, Italy 
continue in the future (Fennell 2020). Because an increased number of visitors may negatively affect natural ecosystems (e.g., Ripple and Beschta 2006, Fernández-Llamazares et al. 2020), the focus of ecotourism should be on both ecological and socioeconomic impacts, especially in protected areas in which nature conservation is the primary aim (Naughton-Treves et al. 2005, DeFries et al. 2007, Jamal and Stronza 2009, Stronza et al. 2019). For this reason, nowadays, the commonly used definition of ecotourism is "responsible travel to natural areas that conserves the environment, sustains the well-being of the local people, and involves interpretation and education" (TIES 2015; see Fennell 2020 for a historical analysis of the key principles of the term). In this sense, ecotourism represents a new challenging socioeconomic and environmental dimension in the sustainable development of protected areas (Fredman and Tyrväinen 2010, Frost and Hall 2012, Job et al. 2017).

In addition to the general definition cited above, ecotourism provides a unique opportunity to convey environmental and biological sustainability principles to the public, focusing in particular on nature conservation and the environmental impact of tourism. This is especially important with regard to touristbased infrastructure, such as park facilities, accommodation, and transport (Van Oosterzee 2000). A well-planned and managed ecotourism development program represents a unique chance to implement a win-win strategy as set out in the UN Agenda 2030 for Sustainable Development Goals (Gale and Hill 2012, Colglazier 2015, UN 2015, Job et al. 2017). There are several benefits to be gained from implementing ecotourism objectives. For example, substantial income can be generated from the local enhancement of natural resources, such as organic farming or sustainable forestry (e.g., Agenda 2030, target 15.2; UN 2015) and other economic activities connected with the cultural landscape close to rural villages; activities such as these can help toward promoting the conservation of wild areas (DeFries et al. 2007, Kremen 2015, Job et al. 2017). Despite these positive effects, there are still two key questions to be addressed regarding ecotourism (Gössling 1999): (1) how can ecotourism activities be planned and managed in a way that minimizes the ecological footprint while maximizing the benefits to society (Job et al. 2017, Mancini et al. 2018); and (2) how can direct and indirect negative impacts on biodiversity conservation and ecosystem functions be effectively curbed (Naughton-Treves et al. 2005, DeFries et al. 2007)? Indeed, a correct framework for sustainable tourism in protected areas should include the active participation of the three main stakeholders, i.e., tourists and tourism operators, local communities and park managers, to reduce the negative impact of ecotourism and economic development on nature conservation to a minimum through initiatives such as sustainable management of tourism, visitors, and natural resources (Jamal and Stronza 2009, Das and Chatterjee 2015, Dangi and Gribb 2018, Leung et al. 2018). Avoiding conflicts between residents and tourists and increasing stakeholder benefits should represent a particularly important goal (Phillips 2003, Lee 2013, Liang and Hui 2016, Jeon et al. 2016, Dangi and Gribb 2018). For example, residents could be involved in tourism planning, thus giving the local community an enhanced sense of control and supervision over the territory they inhabit, to guarantee social-cultural sustainability (Wearing and Wearing 2001, Lee 2013, Peng et al. 2016, Ferrari and Gilli 2018).

\section{Ecotourism in national parks of the Apennines}

National parks are currently attempting to reconcile the dual goals of protecting biodiversity and promoting sustainable development. On account of the rapid growth of tourism in these areas, national parks are globally considered important development tools (Frost and Hall 2012, Manning and Anderson 2012). In fact, national parks are frequently located in underdeveloped and isolated inland zones, often characterized by high unemployment and resulting depopulation.

Within this general picture, mountain areas represent biodiversity hotspots (Hoorn et al. 2018, Rahbek et al. 2019) and are, therefore, ideal candidates as laboratories for enacting UN sustainable development policies (Colglazier 2015). The presence of historical villages is an additional characteristic of Italian national parks in mountain areas, which provides tourists with the choice of a wide range of local, natural, and cultural resources. These include not only natural features but also interesting historical and cultural attractions, together with gastronomic specialities, with the potential to increase benefits for local residents, together with favoring tourism sustainability (Unioncamere 2014). There a couple of reasons why national parks in the Apennine Mountains in Italy are particularly suited for the implementation of the Agenda 2030b (UN 2015): (1) these parks host well-preserved mountain ecosystems, e.g., old-growth beech forests included in the UNESCO world heritage list (Piovesan et al. 2019), which are currently undergoing considerable economic and social development as a result of the promotion of ecotourism (Ferrari and Gilli 2018, Ferrari et al. 2018); (2) these areas have already adhered to the European Charter for Sustainable Tourism in Protected Areas (ECST), a practical management tool that includes a European certification system for sustainable tourism development (Balandina et al. 2012). In this scenario, a knowledge of the major social, cultural, economic, and ecological factors influencing levels of tourist satisfaction represents the best way to maximize the potential benefits of ecotourism (Torres-Sovero et al. 2012) and understand the reasons leading people to visit a specific protected area (Chan and Baum 2007).

We carried out an investigation of the main characteristics of ecotourism in four Italian national parks within the frame of a broader project aimed at promoting sustainable development in Italian mountain areas (Italian Mountain Lab). The four parks selected for our survey are situated along the whole Apennine range, each representing a different administrative, (bio) geographical, and socioeconomic context. This study represents a first attempt to get quantitative feedback on the strengths and weaknesses linked to the implementation of ecotourism in the four national parks surveyed while, at the same time, obtaining information on particular aspects related to the different geographical and social features of each individual park.

The data were gathered using questionnaires administered to hiking guides with park accreditation, aimed at obtaining information based on their experience and qualified perspective. In mountain regions, where hiking represents a significant outdoor activity, often carried out within the boundaries of a national park (Hugo 1999, Ars and Bohanec 2010, Santarém et al. 2015, Dangi and Gribb 2018), hiking guides play a key role as they lead groups to discover the park's most impressive wild areas and cultural landscapes, thus providing proactive interpretative experiences for tourists with respect to sustainable management 
Table 1. Overview of statistics for the four national parks (NP) involved in the study (data from ISPRA 2018). Parks are listed going from north to south along the Apennine range. Data regarding tourist arrivals, nights of stay, and accommodation are reported at a district level, which in many cases includes areas outside the park boundaries, potentially determining an overestimation of visitors. However, data do not include visitors on a one-day trip, who do not use accommodation structures within the park area. This pool of visitors may represent a high percentage of the total tourists visiting NPs in Italy annually, but the actual number is not available because access is not officially checked, and entrance is free. NOTE: FNCP = Foreste Casentinesi, Monte Falterona e Campigna National Park, ALNP = Abruzzo, Lazio e Molise National Park, PNP = Pollino National Park, and ANP = Aspromonte National Park

\begin{tabular}{|c|c|c|c|c|c|c|c|c|c|}
\hline \multirow{2}{*}{$\begin{array}{l}\text { National } \\
\text { Park }\end{array}$} & \multirow{2}{*}{$\begin{array}{c}\text { Founding } \\
\text { Date }\end{array}$} & \multirow{2}{*}{$\begin{array}{l}\text { Area } \\
\text { (ha) }\end{array}$} & \multirow{2}{*}{$\begin{array}{l}\text { Administrative } \\
\text { Districts } \\
\text { (No.) }\end{array}$} & \multirow{2}{*}{$\begin{array}{c}\text { Population } \\
\text { (No.) }\end{array}$} & \multicolumn{2}{|c|}{ Tourist Accommodation } & \multirow{2}{*}{$\begin{array}{l}\text { Arrivals in } \\
\text { Tourist } \\
\text { Structures } \\
\text { (No.) }\end{array}$} & \multirow{2}{*}{$\begin{array}{c}\text { Nights of Stay } \\
\text { in Tourist } \\
\text { Structures } \\
\text { (No.) }\end{array}$} & \multirow{2}{*}{$\begin{array}{c}\text { Hiking } \\
\text { Guides } \\
\text { (No.) }\end{array}$} \\
\hline & & & & & $\begin{array}{c}\text { Structures } \\
(\text { No. })\end{array}$ & $\begin{array}{l}\text { Beds } \\
\text { (No.) }\end{array}$ & & & \\
\hline FCNP & 1993 & 31038 & 11 & 41912 & 310 & 244 & 157564 & 444292 & 96 \\
\hline ALNP & 1923 & 49680 & 24 & 25659 & 191 & 100 & 75846 & 215017 & 32 \\
\hline PNP & 1993 & 171132 & 56 & 147533 & 429 & 7230 & 123380 & 578221 & 70 \\
\hline ANP & 1989 & 64153 & 37 & 271074 & 340 & 302 & 106377 & 282178 & 25 \\
\hline
\end{tabular}

of natural resources and forest conservation solutions (e.g., the role of strict nature reserves and UNESCO world heritage serial sites).

Opinions relating to the public perception of the role of Apennine National Parks in nature conservation, and the services and facilities offered to ecotourists were also collected to pinpoint strategies aimed at improving sustainable tourism, consistent with nature conservation, sustainability education, and communication.

\section{MATERIALS AND METHODS}

\section{Study sites}

The Apennines are a mountain range forming the backbone of the Italian peninsula: they extend approximately in a NW-SE direction for circa $1300 \mathrm{~km}$, with maximum elevation at Gran Sasso (2912 $\mathrm{m}$ a.s.1). There are 11 national parks (NPs) along the Apennine chain out of a total of 24 NPs in Italy, with four being the focus of this study. From north to south the target NPs are: (1) Foreste Casentinesi, Monte Falterona e Campigna National Park (FCNP); (2) Abruzzo, Lazio and Molise National Park (ALNP); (3) Pollino National Park (PNP); and (4) Aspromonte National Park (ANP). These NPs were selected because they are evenly distributed along the Apennine mountain range and span seven administrative regions of Italy (for details see Table 1). Oak or beech forests cover most of the park areas, with a network of towns and villages, especially in the valley bottoms, surrounded by farmland (e.g., Capotorti et al. 2012). Both ALNP and PNP, in particular, are characterized by large areas of grasslands with high biodiversity value (e.g., Primi et al. 2016). In addition, 10 old-growth beech forests in the Italian Apennines, i.e., forests distinguished by the presence of trees in several stages of their structural cycle, including senescent, dead trees, and new cohorts, became a UNESCO World Heritage Serial Site in 2017, as part of the "Ancient and Primeval Beech Forests of the Carpathians and Other Regions of Europe" network (Piovesan et al. 2019). Three of the four NPs in this study host at least one of these sites, and ANP is, at present, a candidate for future expansion of the UNESCO network (Valle Infernale, https://whc.unesco.org/en/ tentativelists/6395/). Data on visitors, tourist accommodations, and number of accredited hiking guides for each of the surveyed NPs are reported in Table 1.

\section{Data collection}

Questionnaires consisting of 85 questions were administered to accredited hiking guides. Of these, 30 questions consisted of answers representing categorical variables (see Table 1A in Appendix 1) and 55 consisted of quantitative answers (see Table $2 \mathrm{~A}$ in Appendix 1). There are a total of 223 guides in the 4 surveyed parks.

With regard to categorical variables, these were derived from both open and closed questions (see Appendix 1, Table 1A). Concerning the quantitative questions, respondents were asked to rate their opinion or agreement on a five-point Likert scale (from 1 = negative or complete disagreement, to $5=$ positive or complete agreement) following consolidated methods (Park and Boo 2010, Diaz-Christiansen et al. 2016, Saayman and Viljoen 2016, Chan et al. 2018). Quantitative questions were grouped into two sections: the first included questions aimed at exploring the hiking guide's own point of view; the second was aimed at gaining information about the feedback that guides receive from tourists regarding conservation and sustainable development (see Appendix 1, Table 2A). In this way we aimed to obtain information concerning both the guides' view of the national park's role and the tourists' awareness of the ecological footprint of ecotourism. Questions were also aimed at evaluating the degree of satisfaction with facilities and services currently offered by national parks to ecotourists.

Questionnaires were sent via email to guides by park administrations. Responses were collected between July and November 2018.

\section{Statistical analyses}

An exploratory, quantitative approach using several multivariate statistical techniques was employed in this research, as set out by Tukey (1977). Principal component analysis (PCA; Mardia et al. 1979), projection pursuit (PP; Loperfido 2018), and linear discriminant analysis (LDA; Mardia et al. 1979) were used to analyze quantitative variables, following a multistep approach, whereas correspondence analysis (CA; Benzécri 1973) was carried out for categorical variables. Statistics were done using R (R Core Team 2017). 
We first investigated our quantitative variables by means of PCA, a multivariate statistical technique that optimally approximates several variables with a smaller number of their linear projections (principal components, PCs; Mardia et al. 1979). Principal components are mutually uncorrelated and ordered to give decreasing contributions to the approximation of the original variables. Graphical representations of PCs can be very helpful in detecting interesting data features. The amount of variance explained by the PCs is quantified by the ratio of the sum of their variances to the sum of the variances of the original variables. The higher the ratio, the better the chosen PCs approximate the original variables and the more reliable their graphical representations are. The PCAs were computed with the $\mathrm{R}$ command princomp $\{$ stats $\}$. Significance of the first principal component variables (loadings) was assessed through a bootstrapping to quantify the extent of contribution for each variable to the first component. Higher values, therefore, reflect the surveyed hiking guides' shared opinions.

Subsequently, an LDA was performed to discriminate the four Italian national parks, i.e., to assess whether there was a difference in the guides' (quantitative) answers between the surveyed NPs. Also known as "supervised classification", such a multivariate statistical technique assigns an observation to the most appropriate group using the features of the groups themselves (Mardia et al. 1979), displaying data projections that best separate the groups. The ratio of the variance between the projected group means and the variance of the projection (sometimes called discriminating ratio) assesses the separation into different groups. The higher the ratio, the better is the separation between groups. Because outliers strongly influence the LDA output, these were identified through a projection pursuit (PP) analysis and subsequently removed (Loperfido 2018). A PP was performed choosing skewness as the projection index, as suggested by Loperfido (2018), which highlighted the advantages of skewnessbased PP for outlier detection. The R package Max Skew was used to perform the PP (Franceschini and Loperfido 2017). The PP output clearly evidenced the presence of five outliers, which remained undetected by PCA. The R function lda $\{$ MASS (Venables and Ripley 2002) was then applied to compute the best discriminating projections. Finally, the significance of the correlations between the projected data and the original data was computed with Fisher's transformation (Johnson et al. 1995).

With regard to categorical variables, a correspondence analysis (CA) was performed to investigate the association between variables (R command CA $\{$ FactoMineR $\}$; Lê et al. 2008). Chisquare test for independence was used to select the variables to be included in the CA by checking the association between each categorical variable and the variable "Park" (i.e., the national park in which each hiking guide works). The CA displays the categories of a pair of variables on the same graph, thus providing a visual insight into the association between the variables themselves (Benzécri 1973). The graphical representation of CA is the biplot, whose points represent either row (row points) or column (column points) profiles. A row point close to a column point suggests that the corresponding categories are positively associated, i.e., they occur together more often than expected if they were independent. A row (column) point far from the origin suggests that the corresponding row (column) profile is very different from the average row (column) profile. The reliability of the biplot is measured through the percentage of association explained by the axes, with higher percentages suggesting stronger reliability.

Descriptive statistics are reported for a number of variables that were not selected for CA. These variables include the level of knowledge about old-growth forests and the rewilding process, two issues that are becoming very relevant in NP planning and management (Navarro and Pereira 2015).

\section{RESULTS}

A total of 78 hiking guides $(\sim 35 \%)$ responded to the questionnaire. The response rate (out of the total number of emails sent for each park) was: $21.9 \%$ in FCNP, $53.1 \%$ in ALNP, 30\% in PNP, and $76 \%$ in ANP. Descriptive statistics (means, standard deviations, and PCA loadings) of the quantitative responses of the 78 hiking guides that participated to the survey is reported in Appendix 1, Table 2A. The respondent's opinion is generally positive (i.e., $>3$ on the rating scale) on most of the surveyed issues: the mean value of responses to the 55 quantitative questions is 3.4 or greater for all the NPs (Table 2), with a few cases (8; i.e., 14.5\%) in which the average score for a single question falls below sufficiency $(<3$; Table 2A in Appendix 1).

Table 2. Means and standard deviations (SD) of quantitative questions across the four surveyed national parks. NOTE: FNCP $=$ Foreste Casentinesi, Monte Falterona e Campigna National Park, ALNP = Abruzzo, Lazio e Molise National Park, PNP = Pollino National Park, and ANP = Aspromonte National Park.

\begin{tabular}{lcc}
\hline \hline Park & Mean & SD \\
\hline FCNP & 3.50 & 0.62 \\
ALNP & 3.46 & 0.56 \\
PNP & 3.36 & 0.74 \\
ANP & 3.70 & 0.58 \\
\hline
\end{tabular}

The PCA provided a first principal component explaining about $24 \%$ of the original variance (Fig. 1). The second principal component supplied a little additional information $(7 \%$ of variance). The output from bootstrapping is shown in Figure 1A and in Table 2A in Appendix 1. The following questions (questions are numbered according to Table $2 \mathrm{~A}$ in Appendix 1) stand out as factors with both high PC1 loading value $(\geq 0.15)$ and a mean score $>3$ : information services (question 14) and efficiency of public services (q. 20) as aspects that tourists consider most important in choosing a location; active planning (q. 30), visitors' environmental awareness (q. 31), investment in water saving (q. 33), energy saving (q. 34), and in better waste management (q. 35), as well as promotion of alternative mobility (q. 36) and environmental quality certification (q. 39) as actions to increase sustainability for tourists staying in the park; waste-disposal management efficiency (q. 42) and alternative mobility availability (q. 43) as factors considered by tourists to evaluate the territory; professionalism/training of staff (q. 47), welcoming and reception system (q. 48), quality that the hotels offer (q. 50), quality of services (q. 51), and adequacy of the sustainable, slow mobility network (q. 53) as the main elements constituting the services offered to tourists. 
Fig. 1. Principal component analysis (PCA) reporting the distribution of hiking guides scores (points) and loading vectors deriving from the 55 quantitative questions, with the first and second principal components explaining $24.3 \%$ and $7.7 \%$ of the variance, respectively.

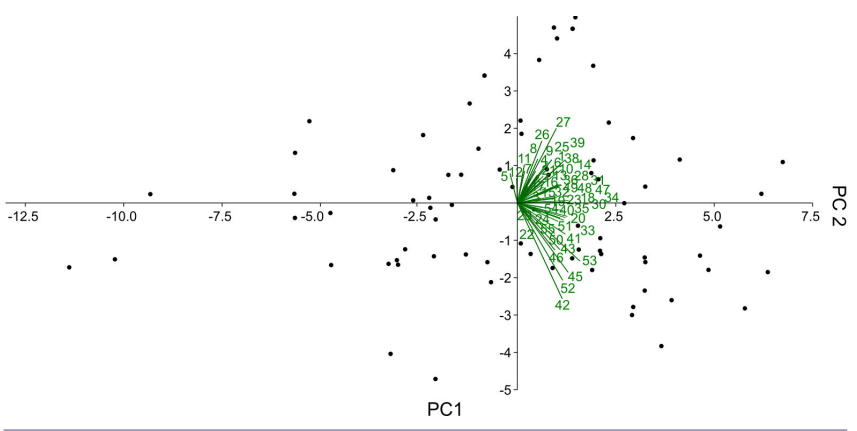

The level of satisfaction with regard to some specific topics was also tested. The answers with significant PC1 loading value (bootstrapping) and insufficient mean score $(<3)$ are: effectiveness of specialized press (q. 23) and environmental labels (q. 27) as means used to choose a hiking guide; water management (q. 40) as an activity considered by tourists to evaluate ecological footprint in the territory; accessibility (q. 45) and quality of the road network (q. 52) as elements of the tourist offer system.

Fig. 2. Principal component 1 (PC1) scores (X axis) vs mean score calculated for each hiking guide ( $\mathrm{Y}$ axis). The line in red shows the threshold indicating sufficiency (score 3) based on the 1 to 5 scale, which guides used to quantify their response. The figure includes data from all four national parks.

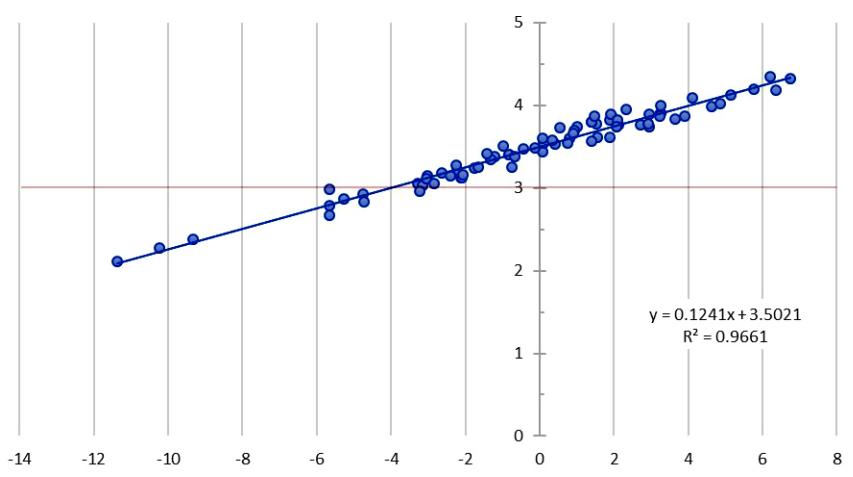

The strong correlation between PC1 scores and the mean score value provided by each single guide is shown in Figure 2. Most of the hiking guides gave an opinion that scored higher than three on average. Only eight cases (10.2\%) exhibited, on average, a negative feedback (Fig. 2): it is noteworthy that guides who expressed a negative evaluation (mean value $<3$ ) also have the most negative PC1 scores.

The LDA highlighted the presence of four groups, each one corresponding to one of the surveyed NPs. There are three best discriminating directions that are shown by the scatter plots (Fig. 3, Fig. 4) and the tables focusing on single significant values
(Appendix 1, Tables 3A, 4A, 5A). The first linear discriminant projection (LD1) separates FCNP-PNP from ALNP-ANP (Fig. $3)$. The discriminating ratio of $\mathrm{LD} 1$ is 0.437 . The variables that most contribute to the discrimination relate to the main reasons for tourists wanting to visit the national park (e.g., horse riding or visitor centers; Table 3A in Appendix 1). Although promotion activities carried out by the parks appear to be less significant, their p-value is also < 0.01 (Table 3A in Appendix 1).

Fig. 3. Scatterplot of first and second linear discriminant projections. 1 = Foreste Casentinesi, Monte Falterona e Campigna National Park (FCNP), 2 = Abruzzo, Lazio e Molise National Park (ALNP), 3 = Pollino National Park (PNP), and 4 = Aspromonte National Park (ANP).

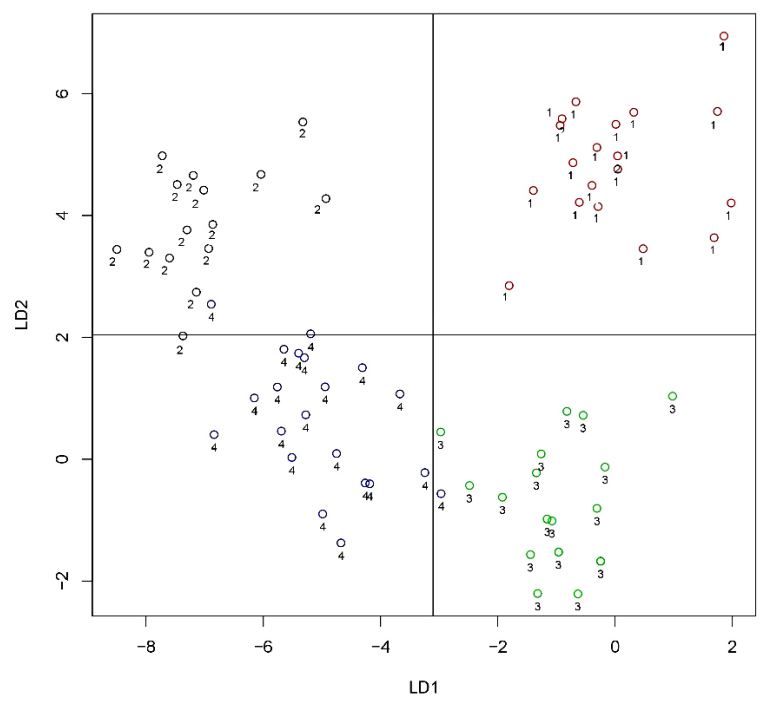

Fig. 4. Scatterplot of second and third linear discriminant projections. $1=$ Foreste Casentinesi, Monte Falterona e Campigna National Park (FCNP), 2 = Abruzzo, Lazio e Molise National Park (ALNP), 3 = Pollino National Park (PNP), and $4=$ Aspromonte National Park (ANP).

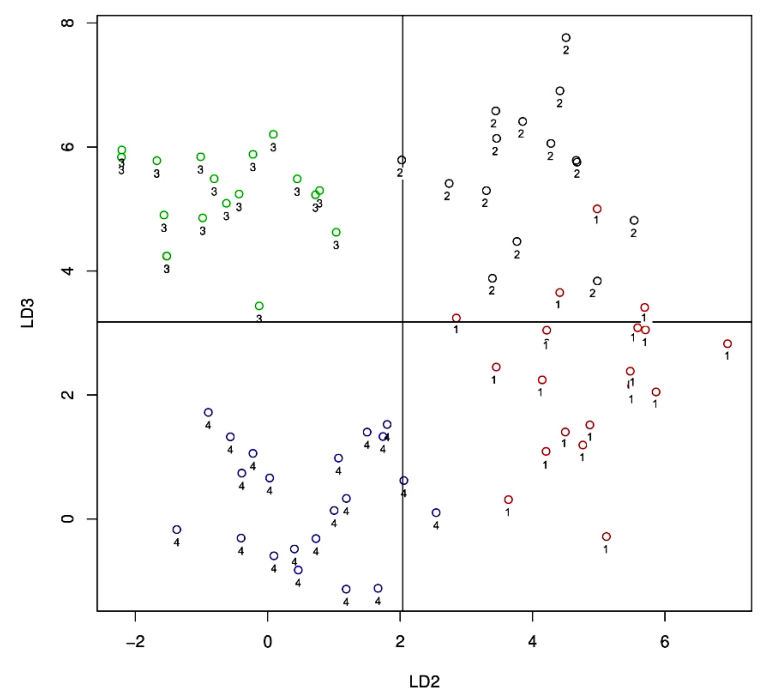


The two parks FCNP-ALNP are separated from PNP-ANP by the second linear discriminant projection (LD2; Fig. 4). The discriminating ratio of LD2 is 0.293 . The variable that is mostly correlated with the discriminating ratio is wildlife sightseeing, representing one of the main reasons for wanting to visit a park (0.493; Table 4A in Appendix 1). According to the hiking guides' opinions, the role of NPs regarding nature conservation is another strongly correlated (0.3903) and significant issue separating ALNP-FCNP and PNP-ANP (Table 4A in Appendix 1).

The third linear discriminant projection (LD3) separates FCNPANP from ALNP-PNP. The discriminating ratio of LD3 is 0.270. In general, the discrimination ratio is mostly correlated with the promotion activities carried out by parks: promotion activities linked to sustainable tourism is the variable showing the highest correlation $(0.535)$ followed by promotion activities in a general sense (0.3868; Table 5A in Appendix 1).

The reported discrimination ratios among parks cannot be attributed to differences in "age" because the one-way ANOVA test returned statistically nonsignificant differences between the age of respondents in the four surveyed NPs. Furthermore, the Chi-square test for independence showed nonsignificant differences among parks attributable to gender.

Biplots resulting from CA include categorical variables found to be significantly associated with "park" (see statistical analyses), namely: "forestry" (opinion on forest cutting in protected areas; $\mathrm{p}<0.05$ ), "education" (forest guides' academic qualifications; $\mathrm{p}$ $<0.10$ ) and "transport" (tourists' preferred means of transport; $\mathrm{p}<0.10)$. The biplot of "parks" vs "transport" and "parks" vs "education" is not shown due to the chaotic configuration of the variables label in the graph.

In the biplot regarding "parks" vs "forestry," almost all the association (94.22\%) is explained by the first axis (Fig. 5). Guides from PNP, FCNP, and ALNP have different views on forest cutting: in PNP and ANP forestry activities are negatively regarded; in FCNP they are viewed as a necessary management activity; and in ALNP they are seen as a remunerative, economic activity. However, $54 \%$ of the interviewed guides provided negative feedback on forest logging in NPs. Only $18 \%$ of them recognized the economic value of forest harvesting activities, while $28 \%$ believed forestry to be a necessary management activity for the future of the forests.

The biplot of the variables "parks" and "transport" explains about $87 \%$ of their association (data not shown). The category "car, camper" is positively associated with FCNP, whereas ALNP is mainly associated with "car," "train," and "coach." In the case of PNP, it is highly associated with "car" and "bus," whereas ANP is associated with "coach," "plane," "train," and "bus." The category "on foot" stands for tourists who prefer walking when moving within the area of the park. Such a category is shared in all NPs except FCNP.

Guides from both ALNP and PNP tend to have a high-school diploma. On the other hand, guides from ANP tend to have a heterogeneous level of education (either very low or very high), whereas most of the guides from FCNP hold an academic degree. Although the biplot is very reliable, accounting for 99.42 of the total association between the two variables (data not shown), no particular configurations worthy of further interpretation were found.
Fig. 5. Biplot of "parks" (blue) vs "forest" (red) variables. Note: FNCP $=$ Foreste Casentinesi, Monte Falterona e Campigna National Park, ALNP = Abruzzo, Lazio e Molise National Park, PNP = Pollino National Park, and ANP = Aspromonte National Park.

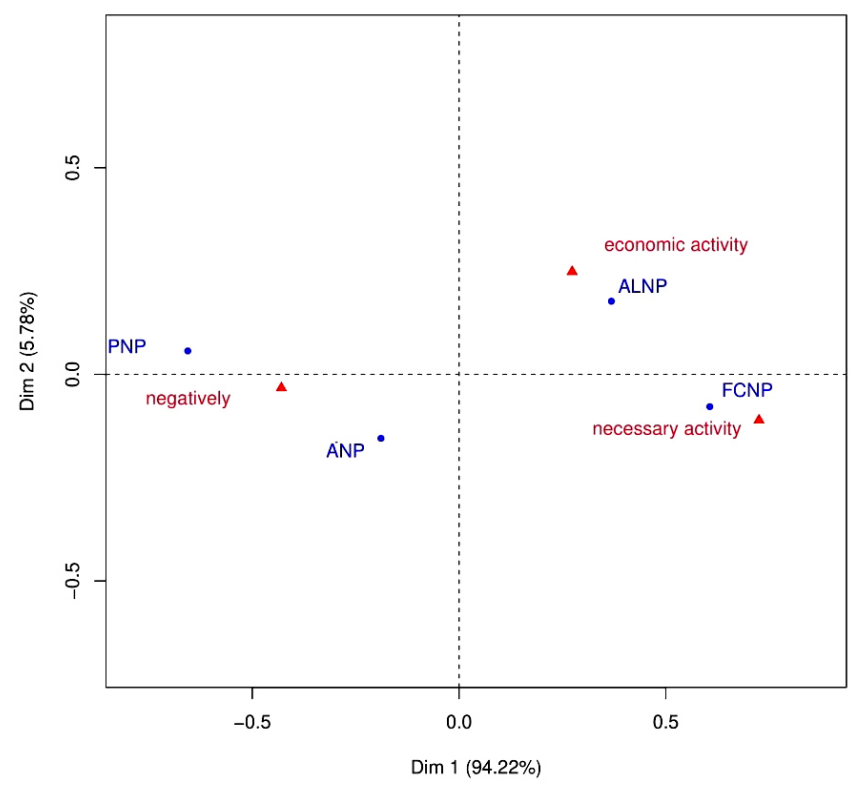

Regarding those categorical variables that were not analyzed through CA, $100 \%$ of the interviewed guides claimed to know what an old-growth forest was and $97 \%$ asserted that they were able to recognize it in the field. The majority of respondents $(91 \%)$ knew that the old-growth beech forests within their national parks are components of a UNESCO World Heritage Serial Site, whereas the small amount of negative feedback $(9 \%)$ came from ANP hiking guides where the UNESCO World heritage nomination is still in progress. Despite these results, hiking guides reported that only $8 \%$ of tourists are choosing nature-based tourism in national parks because of old-growth forests, underlying the need to develop communication programs on conservation. Concerning the ongoing rewilding process on the Italian mountains, $89 \%$ of surveyed hiking guides confirmed that they were aware of it and $68 \%$ of them thought such processes could have positive effects on both the economy and the environment. Finally, when asked to identify which were the best strategies to follow to enhance the ecotourism value of the park (Table 1A, question 28), $41 \%$ of the guides believed that park employees should be involved in upgrading the tourist offers toward a low impact environmental management.

\section{DISCUSSION}

Improving ecotourism sustainability: the key role of hiking guides Although only about $35 \%$ of all accredited hiking guides responded to the questionnaire, we consider this to be an admissible response rate because it is in line with other studies focusing on similar topics (Mitra and Lankford 1999, Cook et al. 2000, Steeh et al. 2001, Connelly et al. 2003). 
Among the answers with higher loading values (see PCA: Fig. 1; Table 2A in Appendix 1), some aspects relevant for sustainable environmental management of protected areas stand out. Overall, the PCA revealed that all interviewed hiking guides across the entire Apennine mountain chain appeared to be sensitive to the theme of sustainability: despite the heterogeneity of the geographical areas analyzed and the diverse characteristics of hiking guides in terms of gender, age, education, and employment (Table 6A in Appendix 1). The first principal component seems to indicate that hiking guides share a common awareness of the strategic aspects with respect to environmental sustainability. These results show, therefore, that the main framework and goals of sustainable development in protected areas in the Apennine range are now a widely held cultural norm among the interviewed hiking guides.

Sustainability in nature-based tourism is a challenging task because visitors' preferences and the criteria for eco-efficient land use can be in opposition to each other (Tyrväinen et al. 2014). Moreover, the relationship between the experience of nature and supporting conservation messaging is complex (e.g., FernándezLlamazares et al. 2020). Concerns about environmental problems do have an important role in prompting conservation engagement (Massingham et al. 2019), although different personal backgrounds may influence an individual's willingness to back environmental initiatives (Dean et al. 2019).

Only $41 \%$ of the surveyed guides responded that they were willing to actively contribute to lowering the environmental impact of the tourist offer, highlighting a lack of awareness about the key role they actually could play to spread knowledge about conservation issues in wildlife-based tourism (e.g., Santarém et al. 2015). Because people are more likely to take or approve conservation actions when they directly experience the natural world (e.g., Miller 2005), hiking guides might be an effective means of conveying a culture of nature conservation to ecotourists by sharing emotional engagement and knowledge (Fernández-Llamazares et al. 2020). Therefore, our results highlight the need to improve conservation messaging strategies in national parks, together with lifelong learning processes to provide hiking guides with up-to-date knowledge on environmentally significant issues. This would encourage tourists to explore wild nature, such as old-growth forests (Chiarucci and Piovesan 2020), and to understand the underlying mechanisms, helping to promote a collective culture oriented toward the conservation of biodiversity and the mitigation of climate change. A new opportunity to enhance the level of hiking guides' knowledge of nature is represented by the transnational joint management plan that is currently being developed for the UNESCO world heritage serial site "Ancient and Primeval Beech Forests of the Carpathians and Other Regions of Europe.”Hiking guides are a key agent in maintaining tourism sustainability in protected areas. Therefore, their role should be given more importance, leading to an enhancement of their sense of responsibility to nature conservation. This research highlights the need for a revision of the accreditation system aimed at including specific training on wilderness and conservation messaging. The goal is to provide hiking guides with increased, up-to-date knowledge and skills on natural processes and solutions aimed at reducing tourist impact on the environment. Assigning an active part in the communication process to trained hiking guides would provide a substantial contribution to people's quality of life, while ensuring protection of the natural heritage.

Hiking guides can also play a leading role in ensuring local communities' engagement with nature conservation and the adoption of agro-environmental measures. In fact, in this study, the guides have demonstrated a willingness to collaborate in reducing tourists' ecological footprint. Local food and its quality were assigned one of the highest scores when guides were asked for rating a number of issues aimed at increasing the sustainability of tourists' sojourns in the park (Table 2A in Appendix 1, q. 37). An ecotourism pilot study in 13 Mediterranean protected areas (DestiMED Project, see https://www.footprintnetwork.org/2019/10/21/ press-release-ecotourism-calculator-destimed/) has recently shown that food and beverages have the strongest ecological impact. The enhancement of typical, local products can represent a win-win solution reducing the ecotourism footprint and revitalizing the supply chain linked to a niche market. In addition, improving the sustainability of natural resources through investment in agroforestry and organic farming would achieve several goals: (1) provide tourists with healthy products; (2) increase income derived from a valuable local food supply chain; (3) help to maintain local varieties and the complex cultural landscape surrounding the towns and villages; and (4) reduce the ecological footprint, especially in those tourism experiences that are highly reliant on fish and meat products (e.g., food and wine tours).

\section{Forest management and sustainable land-use practices}

With regard to forest management, the diverse educational backgrounds of the hiking guides led us to expect to see different ideas in their feedback on the appropriateness and negative effects of forest cutting in protected areas. Data analysis actually revealed a large variation on how forest harvesting activities are perceived by responders. Responses range from completely negative to ones in which forestry actions are considered as necessary management activities. The negative judgements given by the guides from the two southernmost national parks (PNP and ANP) highlight a marked concern for wilderness protection and for the possible negative effects of forest harvesting: in this case, distrust toward forestry sustainability may have its roots in a long history of resource depletion and illegal logging in Southern Italy (e.g., Douglas 1915, Armiero and Hall 2010). On the other hand, silviculture activities in ALNP and FCNP are seen in terms of their economic benefits or simply as necessary forestry management activities.

In the case of ALNP, two issues may explain this view. First, most of the towns within the park's borders (where the majority of the guides reside) are all situated in a secluded valley at relatively high elevation (around 1000-1200 m a.s.l.) characterized by cold, snowy winters (Primi et al. 2016); here, local people still rely on firewood for heating and, as large areas of forest belong to the municipality, firewood is provided for residents at a subsidized price. Second, ALNP is the second oldest national park in Italy (designated in 1923), representing a flagship for nature conservation in the country (e.g., Sievert 1999). In this park, specific regulations (aimed at reaching a compromise between biodiversity conservation and needs of local people) have long governed forestry. The diffuse presence of old-growth forests protected in strict nature reserves (Piovesan et al. 2005) has recently become a mark of identity for the territory, thanks to 
their inclusion in the UNESCO world heritage list. Close-tonature silviculture activities are carried out in the buffer areas, far away from the natural forests within strict reserves, which has built up trust in sustainable forest management among people who are more sensitive to environmental issues.

As for FCNP, a long forest management tradition, dating back to the $16^{\text {th }}$ century, has characterized these territories since Benedictine monks started replacing beech trees with silver fir for economic reasons (Bottacci 2012). Of the four NPs under considerations, this is the only one in which forest management practices (and the resulting landscape) are similar to those of the Alps, with large areas of planted silver fir stands, whereas the rest of the Apennines are mostly characterized by ubiquitous coppices and high forests of oak, hop-hornbeam, or beech. This area saw the establishment of the first strict nature reserve in Italy in 1959 (Sasso Fratino), which aimed to protect old-growth forests from human interferences. Interestingly, despite the presence of strict nature reserves, where even visits on foot are not allowed, most of the local hiking guides $(60 \%)$ still persist in thinking that forests require active management; this belief is probably the result of the wide presence of cultural forest landscapes made up of old, even-aged fir trees, managed with clear cuts and artificial regeneration.

However, the majority $(54 \%)$ of the surveyed guides in all the parks under investigation, views forest cutting as a negative practice for forest ecosystem functioning, highlighting a widespread awareness to the importance of preserving forest integrity and their natural dynamics, rather than using them for wood. Therefore, considering that the strengths of national parks are mainly linked to biodiversity conservation and enjoyment of nature, park administrations could consider a business strategy that promotes the naturalness of forested landscapes by restricting harvesting practices, offsetting the financial loss from forest products with an increase in the number of tourists, and the compensation and benefits deriving from ecosystem services (Naughton-Treves et al. 2005, Ahtikoski et al. 2011, Tuanmu et al. 2016, Job et al. 2017).

\section{Standard of certification}

Our data highlight the generally positive opinions of hiking guides regarding the role of environmental certification as a tool to increase the sustainability of tourists' stays (Table 2A in Appendix 1, q. 39). Certification represents a valuable tool because it aims to support the development of a territory, preserving the ecosystems (e.g., forests) and promoting "social, economic and sustainable management" (see Agenda 2030, goals 8, 12, and 15; UN 2015). Programs for operator certification increase the level of collective knowledge, thus integrating ecological tourism with nature conservation in protected areas (Fennell 2020).

Measuring ecological impacts (e.g., of forests products) is the main challenge in the certification auditing process (van der Ven and Cashore 2018). Italian NPs are ideal candidates for the application of sustainable forest guidelines (see Agenda 2030, target 15.2 indicators, UN 2015) because the plan and rules under which they were set up facilitates the implementation of certification regulations based on concrete sustainability measures. Biodiversity conservation is the first aim in NP core areas, whereas sustainable use of resources may be practiced in buffer areas (e.g., close-to-nature silviculture; Naughton-Treves et al. 2005, DeFries et al. 2007, Job et al. 2017, Pérez-Calderón et al. 2020). This concept is in line with the international management strategy (Joint Management committee) of the European old-growth beech network included in the UNESCO world heritage serial site, in which the nature conservation of over 100,000 hectares of natural forest is aligned with low ecological impact resource use of nearby buffer zones.

Once again, hiking guides represent a meeting point between environmental management policies and local communities: these professional figures are able to interpret and illustrate diverse natural landscapes, the specific regulations that govern them, and the sustainable use of natural resources within the buffer zones.

Certification also constitutes a strong territorial marketing tool, based on the identification of the territory's value and on its specific characteristics (Font et al. 2003). Although it is the perception of hiking guides that tourists pay little attention to certification when choosing a hiking/tourist guide (Table $2 \mathrm{~A}$ in Appendix 1, q. 27), it is nevertheless evident that nature and landscape integrity represent a key attribute determining the selection of travel destinations by tourists, as revealed by the high scores obtained in the questionnaire (Table 2A in Appendix 1, q. 19). Future policy actions through marketing strategies should take tourist demand for nature into consideration with the aim of encouraging local economies to promote travel experiences with a certified low ecological footprint.

Pollino National Park has included the ISO 9001 and 14001 certifications within its policy, as tools for achieving its environmental objectives (Parco Nazionale del Pollino 2019). There is, however, only a small number of key certifications, such as EMAS (eco management and audit scheme used by organizations to improve their environmental performance) ISO 14001 (an international standard for designing and implementing an environmental management system), and the EU ECOLABEL (a label of environmental excellence that defines criteria for tourism accommodation facilities aimed at lowering their environmental impact), among the surveyed parks. Regional and national policies should be more incisive in coordinating actions leading to the adoption of such certification. Furthermore, certification schemes require the implementation of a platform for monitoring the environmental and socioeconomic impact of tourist activities (see Table 1 in Stronza et al. 2019). In this respect, a recent tool developed by the DestiMED project to calculate the ecological footprint of ecotourism in specific areas (https://www. meetnetwork.org/calculator) is an example of a quantitative framework for resource use accounting and natural ecosystem conservation.

\section{Hiking guides' point of view: insights for park managers}

The survey suggests that hiking guides might contribute to park management strategies in several ways. In addition to the active role they might play in conveying the principles of sustainability to tourists, their feedback on management issues represents a possible starting point from which to develop innovations in ecotourism. Concerning the four surveyed national parks, promotion and conservation issues stand out as factors differentiating parks from each other. Both issues might be introduced by parks as topics to work on. For example, ALNP should improve its efforts to promote activities on sustainable tourism, while ANP should better communicate its role on nature 
conservation to visitors. Pollino National Park, on the other hand, appears to be lacking on both issues (LD3 and LD2). Visitor centers, as reasons for tourists wanting to visit the national park (Table 2A in Appendix 1, q. 10) appeared to be a discrimination issue (LD1), but all four NPs were given insufficient rates on the relevance of this topic. Visitor centers perform multiple overlapping functions: promotion of the area; directions to and enhancement of the area's attractions; publicizing the pride and political achievements of the park; and organizing environmental education and other activities addressed to children and schools, in addition to others fundamental NP activities (Pearce 2004). Visitor centers within the parks under investigation could be better exploited to achieve the double goal of improving tourist experience and sharing principles of environmental sustainability among people visiting the park.

Regarding means of transport/mobility for reaching and visiting the park, there is not much differences among NPs. Most visitors reach the park using private motor vehicles. The "on foot" category, resulting from the analysis, appears to be shared by all parks except FCNP. A transition to an eco-efficient transport system to reduce $\mathrm{CO}_{2}$ emissions and pollution, including acoustic pollution, could also be considered by park administrations with the aim of taking care to the tourists' health and the health of the environment itself, at least within the boundaries of a NP.

\section{CONCLUSION}

Hiking guides, by representing the interface between ecotourists, local communities, and park administrations, proved to be a relevant source of information on environmental issues and services provided by these NPs. Thanks to the Italian Mountain Lab project, we are now administering the questionnaires to hiking guides from Alpine protected areas (Italian side). Comparison between the Alps and the Apennines will thus provide valuable information on how the sustainability of ecotourism activities is perceived in territories that are very different in terms of landscapes, culture, attractions, catchment areas, and management strategies.

The governance of protected areas, including the economy linked to ecotourism, is strategic within international agreements for the conservation of the environment and sustainable economic activities. International environmental policies are currently oriented toward recommendations leading to almost a third of the land and marine areas of the world being designated as protected areas by 2030 , with $10 \%$ of the surface of the biosphere being under strict protection (see "Zero draft of the post-2020 global biodiversity framework" by the Open-ended Working Group on the Post 2020 Global Biodiversity Framework, CBD 2020; see also the new "Biodiversity strategy" of EU Commission, EC 2020). In this sense, ecotourism may represent important backup support for environmental policies, producing income that could be redistributed to local populations for restoration activities, conservation, and sustainable management of natural resources, etc. Limiting the ecological footprint of tourism remains the main challenge in protected areas and the present study highlights how the figure of the hiking guide could contribute not only to improving cultural awareness of conservation issues, but also to encouraging activities with a low environmental impact. It is, therefore, necessary to develop a system of indicators, in line with the objectives of Agenda 2030, with the aim of measuring the economic, social, cultural, and biological impact of tourism in protected areas. At the same time, improving scientific communication and education activities organized by national parks in close connection with universities should be a priority task to spread the culture of sustainable development. As highlighted by the questionnaire, the ability to communicate the relevance of sustainable development issues, together with the important role of hiking guides as a bridge between management bodies and park users, gives these key figures a strategic role in the long and complex process of safeguarding life on Earth.

\section{Responses to this article can be read online at: https://www.ecologyandsociety.org/issues/responses. php/11996}

\begin{abstract}
Acknowledgments:
This survey was carried out thanks to the basic support of park officials. In particular, we thank Nevio Agostini and Davide Alberti from Foreste Casentinesi, Monte Falterona, and Campigna National Park, Cinzia Sulli and Carmelo Gentile from Abruzzo, Lazio, and Molise National Park, Giuseppe de Vivo, Vittoria Marchianò, and Aldo Schettino from Pollino National Park, and Antonio Siclari from Aspromonte National Park. The study was supported by MIUR (Ministry for Education, University and Research) initiative Department of Excellence (Law 232/2016) and by the FISR-MIUR Italian Mountain Lab project. We also thank the anonymous reviewers for providing thoughtful and constructive comments.
\end{abstract}

\section{Data Availability:}

The datalcode that support the findings of this study are openly available in Open Science Framework at https://doi.org/10.17605/ OSF.IO/8ZJTN.

\section{LITERATURE CITED}

Ahtikoski, A., S. Tuulentie, V. Hallikainen, V. Nivala, E. Vatanen, L. Tyrväinen, and H. Salminen. 2011. Potential trade-offs between nature-based tourism and forestry, a case study in Northern Finland. Forests 2:894-912. https://doi.org/10.3390/ $\underline{\mathrm{f2040894}}$

Armiero, M., and M. Hall. 2010. Nature and history in modern Italy. Ohio University Press, Athens, Ohio, USA.

Ars, M. S., and M. Bohanec. 2010. Towards the ecotourism: a decision support model for the assessment of sustainability of mountain huts in the Alps. Journal of Environmental Management 91(12):2554-2564. https://doi.org/10.1016/j.jenvman.2010.07.006

Balandina, A., L. Lovén, O. Ostermann, and R. Partington. 2012. European charter parks - a growing network for sustainable tourism development in protected areas. Parks 18(2):132. https:// doi.org/10.2305/IUCN.CH.2012.PARKS-18-2.AB.en

Bartelmus, P. 1986. Environment and development. Allen and Unwin, Boston, Massachusetts, USA. 
Benzécri, J.-P. 1973. L'analyse des données: l'analyse des correspondances. Volume 2. Dunod, Paris, France.

Boley, B. B., and M. Uysal. 2014. Competitive synergy through practicing triple bottom line sustainability: evidence from three hospitality case studies. Tourism and Hospitality Research 13 (4):226-238. https://doi.org/10.1177/1467358414528528

Boo, E. 1990. Ecotourism: the potentials and pitfalls. Volume 1. World Wildlife Fund, Washington, D.C., USA.

Bottacci, A. 2012. Cenni storici sulla Riserva naturale biogenetica di Camaldoli. Pages 27-54 in A. Bottacci, editor. La Riserva naturale biogenetica di Camaldoli, 1012-2012. Mille anni di rapporto uomo-foresta. CFS/UTB Pratovecchio, Tuscany, Italy.

Capotorti, G., L. Zavattero, I. Anzellotti, S. Burrascano, R. Frondoni, M. Marchetti, M. Marignani, D. Smiraglia, and C. Blasi. 2012. Do national parks play an active role in conserving the natural capital of Italy? Plant Biosystems 146(2):258-265. https://doi.org/10.1080/11263504.2012.695298

Chan, C.-S., S. K. Yuen, X. Duan, and L. M. Marafa. 2018. An analysis of push-pull motivations of visitors to country parks in Hong Kong. World Leisure Journal 60(3):191-208. https://doi. org/10.1080/16078055.2018.1496527

Chan, J. K. L., and T. Baum. 2007. Motivation factors of ecotourists in ecolodge accommodation: the push and pull factors. Asia Pacific Journal of Tourism Research 12(4):349-364. https://doi.org/10.1080/10941660701761027

Chiarucci, A., and G. Piovesan. 2020. Need for a global map of forest naturalness for a sustainable future. Conservation Biology 34(2):368-372 https://doi.org/10.1111/cobi.13408

Choi, H. C., and E. Sirakaya. 2006. Sustainability indicators for managing community tourism. Tourism Management 27:1274-1289. https://doi.org/10.1016/j.tourman.2005.05.018

Clarke, J. 1997. A framework of approaches to sustainable tourism. Journal of Sustainable Tourism 5(3):224-233. https://doi. org/10.1080/09669589708667287

Colglazier, W. 2015. Sustainable development agenda: 2030. Science (3496252):1048-1050. https://doi.org/10.1126/science. aad2333

Connelly, N. A., T. L. Brown, and D. J. Decker. 2003. Factors affecting response rates to natural resource-focused mail surveys: empirical evidence of declining rates over time. Society and Natural Resources 16(6):541-549. https://doi.org/10.1080/08941920309152

Convention on Biological Diversity (CBD). 2020. Zero draft of the post-2020 global biodiversity framework. CBD, Montreal, Quebec, Canada. [online] URL: https://www.cbd.int/doc/c/ efb0/1f84/a892b98d2982a829962b6371/wg2020-02-03-en.pdf

Cook, C., F. Heath, and R. L. Thompson. 2000. A meta-analysis of response rates in web-or internet-based surveys. Educational and Psychological Measurement 60(6):821-836. https://doi. org/10.1177/00131640021970934

Dangi, T. B., and W. J. Gribb. 2018. Sustainable ecotourism management and visitor experiences: managing conflicting perspectives in Rocky Mountain National Park, USA. Journal of Ecotourism 17(3):338-358. https://doi.org/10.1080/14724049.2018.1502250
Das, M., and B. Chatterjee. 2015. Ecotourism: a panacea or a predicament? Tourism Management Perspectives 14:3-16. https:// doi.org/10.1016/j.tmp.2015.01.002

Dean, A. J., A. G. Barnett, K. A. Wilson, and G. Turrell. 2019. Beyond the 'extinction of experience' - novel pathways between nature experience and support for nature conservation. Global Environmental Change 55:48-57. https://doi.org/10.1016/j. gloenvcha.2019.02.002

DeFries, R., A. Hansen, B. L. Turner, R. Reid, and J. Liu. 2007. Land use change around protected areas: management to balance human needs and ecological function. Ecological Applications 17 (4):1031-1038. https://doi.org/10.1890/05-1111

Diaz-Christiansen, S., T. López-Guzmán, J. C. Pérez Gálvez, and G. A. Muñoz Fernández. 2016. Wetland tourism in natural protected areas: Santay Island (Ecuador). Tourism Management Perspectives 20:47-54. https://doi.org/10.1016/j.tmp.2016.07.005

Douglas, N. 1915. Old calabra. Houghton Mifflin, Boston, Massachusetts, USA.

Dudley, N., editor. 2008. Guidelines for applying protected area management categories: developing capacity for a protected planet. IUCN, Gland, Switzerland. https://portals.iucn.org/library/sites/ library/files/documents/PAG-021.pdf https://doi.org/10.2305/IUCN. CH.2008.PAPS.2.en

Elkington, J. 1997. Cannibals with forks: the triple bottom line of 21 st century business. Capstone, Oxford, UK.

Elkington, J. 1998. Partnerships from cannibals with forks: the triple bottom line of 21st-century business. Environmental Quality Management 8(1):37-51. https://doi.org/10.1002/tqem.3310080106

Elkington, J. 2004. Enter the triple bottom line. Pages 1-16 in A. Henriques and J. Richardson, editors. The triple bottom line: does it all add up. Hearthscan, London, UK. https://doi. org/10.4324/9781849773348

European Commission (EC). 2020. European Union biodiversity strategy for 2030. Bringing nature back into our lives. European Commission, Brussels, Belgium. [online] URL: https://eur-lex. europa.eu/legal-content/EN/TXT/?qid=1590574123338\&uri= CELEX:52020DC0380

Farrell, B. 1992. Tourism as an element in sustainable development. Pages 115-134 in V. L. Smith and W. R. Eadington, editors. Tourism alternatives: potentials and problems in the development of tourism. University of Pennsylvania Press, Philadelphia, USA. https://doi.org/10.9783/9781512807462-011

Fennell, D. A. 2020. Ecotourism. Abingdon, Oxon, UK.

Fernández-Llamazares, Á, S. Fraixedas, A. Brias-Guinart, and J. Terraube. 2020. Principles for including conservation messaging in wildlife-based tourism. People and Nature 2:596-607. https:// doi.org/10.1002/pan3.10114

Ferrari, S., and M. Gilli. 2018. Sustainable tourism in natural protected areas: the points of view of hosts and guests in Sila National Park. Pages 39-55 in I. Azara, E. Michopoulou, A. Clarke, D. Taff, and F. Niccolini, editors. Tourism, health, wellbeing and protected areas. CABI, Wallingford, UK. https://doi. org/10.1079/9781786391315.0039 
Ferrari, S., M. Gilli, and L. Bollani. 2018. Analysis and segmentation of visitors in a natural protected area: marketing implications. Pages 39-62 in D. Batabyal, editor. Managing sustainable tourism resources. IGI Global, Hershey, Pennsylvania, USA. https://doi.org/10.4018/978-1-5225-5772-2.ch003

Font, X., R. Sanabria, and E. Skinner. 2003. Sustainable tourism and ecotourism certification: raising standards and benefits. Journal of Ecotourism 2(3):213-218. https://doi.org/10.1080/147$\underline{24040308668145}$

Franceschini, C., and N. Loperfido. 2017. MaxSkew: orthogonal data projections with maximal skewness. $\mathrm{R}$ package version 1.1. R Foundation for Statistical Computing, Vienna, Austria. [online] URL: https://rdrr.io/cran/MaxSkew/man/MaxSkew.html

Fredman, P., and L. Tyrväinen. 2010. Frontiers in nature-based tourism. Scandinavian Journal of Hospitality and Tourism 10 (3):177-189. https://doi.org/10.1080/15022250.2010.502365

Frost, W., and C. M. Hall. 2012. American invention to international concept: the spread and evolution of national parks. Pages 20-44 in W. Frost and C. M. Hall, editors. Tourism and national parks: international perspectives on development, histories and change. Taylor and Francis, Abingdon, UK. https://doi. org/10.4324/9780203884201

Gale, T., and J. Hill. 2012. Ecotourism and environmental sustainability: an introduction. Pages 3-16 in T. Gale, editor. Ecotourism and environmental sustainability: principles and practice. Routledge, London, UK. https://doi.org/10.4324/9781315578767

Garay, L., and X. Font. 2012. Doing good to do well? Corporate social responsibility reasons, practices and impacts in small and medium accommodation enterprises. International Journal of Hospitality Management 31(2):329-337. https://doi.org/10.1016/ j.ijhm.2011.04.013

Gössling, S. 1999. Ecotourism: a means to safeguard biodiversity and ecosystem functions? Ecological Economics 29(2):303-320. https://doi.org/10.1016/s0921-8009(99)00012-9

Hoorn, C., A. Perrigo, and A. Antonelli. 2018. Mountains, climate and biodiversity: an introduction. Pages 1-15 in C. Hoorn, A. Perrigo, and A. Antonelli, editors. Mountains, climate and biodiversity. John Wiley and Sons, Hoboken, New Jersey, USA. https://doi.org/10.7287/peerj.preprints. 27768

Hugo, M. L. 1999. A comprehensive approach towards the planning, grading and auditing of hiking trails as ecotourism products. Current Issues in Tourism 2(2-3):138-173. https://doi. org/10.1080/13683509908667849

Istituto Superiore per la Protezione e la Ricerca Ambientale (ISPRA). 2018. Turismo nei parchi. Annuario dei dati ambientali. ISPRA, Rome, Italy. [online] URL: https://annuario. isprambiente.it/ada/basic/7032

Jamal, T., and A. Stronza. 2009. Collaboration theory and tourism practice in protected areas: stakeholders, structuring and sustainability. Journal of Sustainable Tourism 17(2):169-189. https://doi.org/10.1080/09669580802495741

Jeon, M. M., M. (Michelle) Kang, and E. Desmarais. 2016. Residents' perceived quality of life in a cultural-heritage tourism destination. Applied Research in Quality of Life 11(1):105-123. https://doi.org/10.1007/s11482-014-9357-8

Job, H., S. Becken, and B. Lane. 2017. Protected areas in a neoliberal world and the role of tourism in supporting conservation and sustainable development: an assessment of strategic planning, zoning, impact monitoring, and tourism management at natural world heritage sites. Journal of Sustainable Tourism 25(12):1697-1718. https://doi.org/10.1080/09669582.2017.1377432

Johnson, N. L., S. Kotz, and N. Balakrishnan. 1995. Continuous univariate distributions. Volume 2. Wiley, New York, New York, USA.

Kremen, C. 2015. Reframing the land-sparing/land-sharing debate for biodiversity conservation. Annals of the New York Academy of Sciences 1355(1):52-76. https://doi.org/10.1111/ nyas. 12845

Laarman, J. G., and P. B. Durst. 1987. Nature travel in the tropics. Journal of Forestry 85(5):43-46.

Lê, S., J. Josse, and F. Husson. 2008. FactoMineR: an R package for multivariate analysis. Journal of Statistical Software 25 (1):1-18. https://doi.org/10.18637/jss.v025.i01

Lee, T. H. 2013. Influence analysis of community resident support for sustainable tourism development. Tourism Management 34:37-46. https://doi.org/10.1016/j.tourman.2012.03.007

Leung, Y.-F., A. Spenceley, G. Hvenegaard, and R. Buckley. 2018. Tourism and visitor management in protected areas: guidelines for sustainability. IUCN, Gland, Switzerland. https://doi.org/10.2305/ IUCN.CH.2018.PAG.27.en

Liang, Z.-X., and T.-K. Hui. 2016. Residents' quality of life and attitudes toward tourism development in China. Tourism Management 57:56-67. https://doi.org/10.1016/j.tourman.2016.05.001

Loperfido, N. 2018. Skewness-based projection pursuit: a computational approach. Computational Statistics and Data Analysis 120:42-57. https://doi.org/10.1016/j.csda.2017.11.001

Mancini, M. S., M. Evans, K. Iha, C. Danelutti, and A. Galli. 2018. Assessing the ecological footprint of ecotourism packages: a methodological proposition. Resources 7(2):38. https://doi. org/10.3390/resources7020038

Manning, R. E., and L. E. Anderson. 2012. Managing outdoor recreation: case studies in the national parks. CABI, Wallingford, UK.

Mardia, K. V., J. T. Kent, and J. M. Bibby. 1979. Multivariate analysis. Academic Press, London, UK.

Massingham, E., R. A. Fuller, and A. J. Dean. 2019. Pathways between contrasting ecotourism experiences and conservation engagement. Biodiversity and Conservation 28(4):827-845. https:// doi.org/10.1007/s10531-018-01694-4

Miller, G. 2001. The development of indicators for sustainable tourism: results of a Delphi survey of tourism researchers. Tourism Management 22:351-362. https://doi.org/10.1016/ $\underline{\mathrm{S} 0261-5177(00) 00067-4}$ 
Miller, J. R. 2005. Biodiversity conservation and the extinction of experience. Trends in Ecology and Evolution 20(8):430-434. https:// doi.org/10.1016/j.tree.2005.05.013

Mitra, A., and S. Lankford. 1999. Research methods in park, recreation and leisure services. Sagamore, Champaign, Illinois, USA.

Molina-Azorín, J. F., and X. Font. 2016. Mixed methods in sustainable tourism research: an analysis of prevalence, designs and application in JOST (2005-2014). Journal of Sustainable Tourism 24(4):549-573. https://doi.org/10.1080/09669582.2015.1073739

Mondéjar-Jiménez, J., J. A. Mondéjar-Jiménez, M. VargasVargas, and J. Gázquez-Abad. 2012. Personal attitudes in environmental protection. International Journal of Environmental Research 6(4):1039-1044. https://doi.org/10.22059/IJER.2012.574

Mowforth, M., and I. Munt. 2003. Tourism and sustainability. New tourism in the Third World. Routledge, London, UK. https:// doi.org/10.4324/9780203891056

Naughton-Treves, L., M. B. Holland, and K. Brandon. 2005. The role of protected areas in conserving biodiversity and sustaining local livelihoods. Annual Review of Environment and Resources 30 (1):219-252. https://doi.org/10.1146/annurev.energy.30.050504.164507

Navarro, L. M., and H. M. Pereira. 2015. Rewilding abandoned landscapes in Europe. Pages 3-23 in H. M. Pereira and L. M. Navarro, editors. Rewilding European landscapes. Springer, Berlin, Germany. https://doi.org/10.1007/978-3-319-12039-3 1

Parco Nazionale del Pollino. 2019. Policy of the park. Government of Italy, Rome, Italy. https://parcopollino.gov.it/images/2017/ politica aziendale.pdf

Park, E., and S. Boo. 2010. An assessment of convention tourism's potential contribution to environmentally sustainable growth. Journal of Sustainable Tourism 18(1):95-113. https://doi. org/10.1080/09669580903147936

Pearce, D., E. Barbier, and A. Markandya. 1990. Sustainable development, economics and environmental in the Third World. Edward Elgar, Aldershot, UK.

Pearce, P. 2004. The functions and planning of visitor centres in regional tourism. Journal of Tourism Studies 15(1):8.

Peng, J., X. Chen, and J. Wang. 2016. Applying relative deprivation theory to study the attitudes of host community residents towards tourism: the case study of the Zhangiiang National Park, China. Current Issues in Tourism 19(7):734-754. https://doi.org/10.1080/13683500.2013.877876

Pérez-Calderón, E., J. M. Prieto-Ballester, V. Miguel-Barrado, and P. Milanés-Montero. 2020. Perception of sustainability of Spanish national parks: public use, tourism, and rural development. Sustainability 12:1333. https://doi.org/10.3390/ $\underline{\text { su12041333 }}$

Phillips, A. 2003. Turning ideas on their head. George Wright Forum 20:8-32.

Piovesan, G., A. Di Filippo, A. Alessandrini, F. Biondi, and B. Schirone. 2005. Structure, dynamics and dendroecology of an old- growth Fagus forest in the Apennines. Journal of Vegetation Science 16(1):13-28. https://doi.org/10.1111/j.1654-1103.2005. $\underline{\text { tb02334.x }}$

Piovesan, G., F. Biondi, M. Baliva, G. De Vivo, V. Marchianò, A. Schettino, and A. Di Filippo. 2019. Lessons from the wild: slow but increasing long-term growth allows for maximum longevity in European beech. Ecology 100(9):e02737. https://doi. org/10.1002/ecy. 2737

Primi, R., G. Filibeck, A. Amici, C. Bückle, L. Cancellieri, A. Di Filippo, C. Gentile, A. Guglielmino, R. Latini, L. D. Mancini, S. A. Mensing, C. M. Rossi, F. Rossini, A. Scoppola, C. Sulli, R. Venanzi, B. Ronchi, and G. Piovesan. 2016. From Landsat to leafhoppers: a multidisciplinary approach for sustainable stocking assessment and ecological monitoring in mountain grasslands. Agriculture, Ecosystems and Environment 234:118-133. https://doi.org/10.1016/j.agee.2016.04.028

R Core Team. 2017. R: a language and environment for statistical computing. R Foundation for Statistical Computing, Vienna, Austria. [online] URL: https://www.R-project.org/

Rahbek, C., M. K. Borregaard, A. Antonelli, R. K. Colwell, B. G. Holt, D. Nogues-Bravo, C. M. Ø. Rasmussen, K. Richardson, M. T. Rosing, R. J. Whittaker, and J. Fjeldså. 2019. Building mountain biodiversity: geological and evolutionary processes. Science 365(6458):1114-1119. https://doi.org/10.1126/science. aax0151

Ripple, W. J., and R. L. Beschta. 2006. Linking a cougar decline, trophic cascade, and catastrophic regime shift in Zion National Park. Biological Conservation 133(4):397-408. https://doi. org/10.1016/j.biocon.2006.07.002

Roberts, S., and J. Tribe. 2008. Sustainability indicators for small tourism enterprises - an exploratory perspective. Journal of Sustainable Tourism 16(5):575-594. https://doi.org/10.1080/09669580802159644

Saayman, M., and A. Viljoen. 2016. Who are wild enough to hike a wilderness trail? Journal of Outdoor Recreation and Tourism 14:41-51. https://doi.org/10.1016/j.jort.2016.04.004

Santarém, F., R. Silva, and P. Santos. 2015. Assessing ecotourism potential of hiking trails: a framework to incorporate ecological and cultural features and seasonality. Tourism Management Perspectives 16:190-206. https://doi.org/10.1016/j.tmp.2015.07.019

Sievert, J. 1999. Abruzzo National Park: land of dreams. Environment and History 5:293-307.

Spangenberg, G. H. 2002. Environmental space and the prism of sustainability: frameworks for indicators measuring sustainable development. Ecological Indicators 2(3):295-309. https://doi. org/10.1016/S1470-160X(02)00065-1

Steeh, C., N. Kirgis, B. Cannon, and J. DeWitt. 2001. Are they really as bad as they seem? Nonresponse rates at the end of the twentieth century. Journal of Official Statistics 17(2):227-247. [online] URL: https://www.scb.se/contentassets/ca21efb41fee47d293bbee 5 bf 7 be $7 \mathrm{fb} 3 /$ are-they-really-as-bad-as-they-seem-nonresponseratesat-the-end-of-the-twentieth-century.pdf 
Stoddard, J. E., C. E. Pollard, and M. R. Evans. 2012. The triple bottom line: a framework for sustainable tourism development. International Journal of Hospitality and Tourism Administration 13(3):233-258. https://doi.org/10.1080/15256480.2012.698173

Stronza, A. L., C. A. Hunt, and L. A. Fitzgerald. 2019. Ecotourism for conservation? Annual Review of Environment and Resources 44:229-253. https://doi.org/10.1146/annurevenviron-101718-033046

Swarbrooke, J. 1999. Sustainable tourism management. CABI, Wallingford, UK. https://doi.org/10.1079/9780851993140.0000

The International Ecotourism Society (TIES). 2020. What is ecotourism. The International Ecotourism Society. [online] URL: http://www.ecotourism.org/what-is-ecotourism

Torres-Sovero, C., J. A. González, B. Martín-López, and C. A. Kirkby. 2012. Social-ecological factors influencing tourist satisfaction in three ecotourism lodges in the southeastern Peruvian Amazon. Tourism Management 33(3):545-552. https:// doi.org/10.1016/j.tourman.2011.06.008

Tuanmu, M.-N., A. Viña, W. Yang, X. Chen, A. M. Shortridge, and J. Liu. 2016. Effects of payments for ecosystem services on wildlife habitat recovery. Conservation Biology 30(4):827-835. https://doi.org/10.1111/cobi.12669

Tukey, J. W. 1977. Exploratory data analysis. Pearson, London, UK.

Tyrrell, T., C. M. Paris, and V. Biaett. 2013. A quantified triple bottom line for tourism: experimental results. Journal of Travel Research 52(3):279-293. https://doi.org/10.1177/0047287512465963

Tyrväinen, L., M. Uusitalo, H. Silvennoinen, and E. Hasu. 2014. Towards sustainable growth in nature-based tourism destinations: clients' views of land use options in Finnish Lapland. Landscape and Urban Planning 122:1-15. https://doi.org/10.1016/j. landurbplan.2013.10.003

Unioncamere. 2014. Aree protette italiane in cifre. Unioncamere, Rome, Italy. [online] URL: http://www.unioncamere.gov.it/ download/3715.html

United Nations (UN). 2015. Transforming our world: the 2030 agenda for sustainable development. United Nations, New York, New York, USA. [online] URL: https://sustainabledevelopment. un.org/post2015/transformingourworld

van der Ven, H., and B. Cashore. 2018. Forest certification: the challenge of measuring impacts. Current Opinion in Environmental Sustainability 32:104-111. https://doi.org/10.1016/ j.cosust.2018.06.001

Van Oosterzee, P. 2000. Ecotourism and biodiversity conservation - two way track. Pacific Conservation Biology 6(2):89-93. https:// doi.org/10.1071/PC000089

Venables, W. N., and B. D. Ripley. 2002. Modern applied statistics with $S$. Fourth edition. Springer, New York, New York, USA. https://doi.org/10.1007/978-0-387-21706-2

Wearing, S., and B. Wearing. 2001. Conceptualizing the selves of tourism. Leisure Studies 20:143-159. https://doi.org/10.1080/026$\underline{14360110051631}$
Weaver, D. 2006. Sustainable tourism: theory and practice. Elsevier, London, UK.

Weaver, D. 2010. Geopolitical dimensions of sustainable tourism. Tourism Recreation Research 35(1):47-53. https://doi. org/10.1080/02508281.2010.11081618

Wilson, E. O. 2016. Half-earth: our planet's fight for life. WW Norton and Company, New York, New York, USA.

World Commission on Environment and Development (WCED). 1987. Report of the World Commission on Environment and Development. Our common future. United Nations, New York, New York, USA.[online] URL: https://sustainabledevelopment. un.org/content/documents/5987our-common-future.pdf 


\section{APPENDIX 1 \\ Hiking guides questionnaire: questions and statistics}

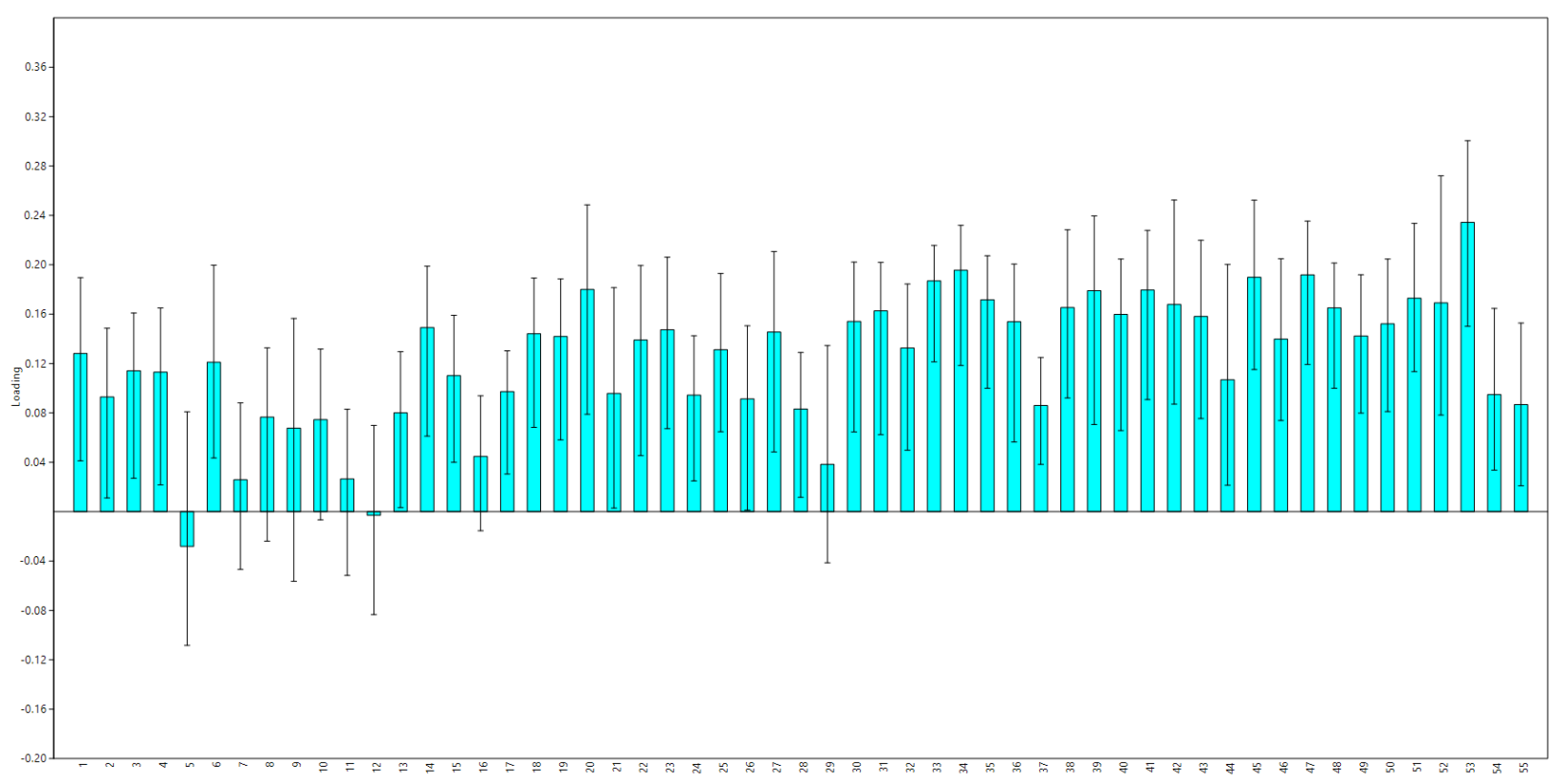

Figure A1 Bootstrap analysis of correlations between the first principal component (PC1) and the original variables.

Table A1 Questions whose answers are categorical variables. Numbers (No.) with * identify closeended questions, with the set of possible answers being reported in parentheses. Numbers without* are open-ended questions.

\section{No. Questions}

1* Gender (Male; Female; Transgender)

2 Age

3 Citizenship

4 Educational qualifications

5 First language

6 Second language

7 Other languages spoken

$8^{*} \quad$ Is guiding tourists on hiking trails your main job? (Yes; No)

9 Do you have any other form of employement? 
10* In which National Park are you an accredited hiking guide? (FCNP; ALNP; PNP; ANP)

11* Do you know what an old-growth forest is? (Yes; No)

12* Would you be able to identify an old-growth forest? (Yes; No)

13* Did you knov
(Yes; No)

14* Do you think that old-growth forests are the main reason why tourists choose to visit the park? (Yes; No)

15* How do you judge forestry management practices in a protected area? (Negatively due to impact on wilderness; A necessary management activity; An economic activity)

16* Do you know what rewilding consists of, i.e. the returning to nature of rural areas? (Yes; No)

17* What do you think about the ongoing rewilding process? (Positive; Negative; No opinion)

18* In your opinion, biodiversity is: (At risk due to human pressure and climate change; The result of natural adaptation; I have no opinion on the matter)

19 From which part of the world do over $50 \%$ of park visitors come from?

20 From which part of the world do $25-50 \%$ of park visitors come from?

21 From which part of the world do the remaining 0-25\% of park visitors come from?

22 How long do your guided tourist excursions with the same tourist/group last, on average? (Days or part of a day)

23* How many people do your excursion/guided groups usually consist of? Indicate no more than 2 options. (Single; Families; Up to 4 people; Up to 12 people; Up to 24 people; More than 50 people) In your experience, what form of transport do most people use to reach the park area? Indicate no

24* more than 2 options. (Plane; Train; Car; Caravan; Camper; Coach; Bus; Commercial vehicle; Motorbike; Bicycle; On foot)

Once inside the park, how do people move from one area to another? Indicate no more than 2 options. (Car; Coach; Bus; Commercial vehicle; Motorbike; Bicycle; On foot)

How would you describe tourists who ask for your services as a hiking guide? (All-inclusive; Emotional/dreamer; Passionate; Nature lover; Organizer; Occasional; Adventurous; Regular visitor)

What are the most popular excursions chosen by tourists? Indicate no more than 3 options.

(Enogastronomic tours; Hiking; Narrative hiking itineraries; Walking; Horse-riding; Educational workshops; Mountain biking; Canooing; Kayaking; Rafting; Downhill mountain biking; Nordic walking; Rock climbing)

In your opinion, what would be the best strategy to enhance the ecotourism value of the park? (Give importance to strategic tourist attractions; Highlight new tourist destinations; Amplify and diversify

28* the tourist offer; Digitalisation; Improve infrastructure; Update tourist offer with the aim of developping management practices with low environmental impact, involving employees working in the sector; All answers, except number 5)

29 What do you think about the role of bodies/agencies promoting tourism in the park?

30* Does the park organize training activities for guides? (Yes; No) 
Table A2 Quantitative question scores. Mean values for all four National Parks (Mean) and relative standard deviation (SD) together with mean values for each National Park are reported. For each question, PC1 loading values are also shown. PCA loading values in bold highlight the positive correlated values from bootstrapping. Numbers (No.) in red highlight questions aimed to receive the hiking guides' own opinion, whereas numbers in black identify questions aimed to know the feedback that hiking guides get from tourists. $1=$ Foreste Casentinesi, Monte Falterona and Campigna National Park (FCNP); 2 = Abruzzi, Lazio and Molise National Park (ALNP); 3 = Pollino National Park (PNP); $4=$ Aspromonte National Park (ANP).

\begin{tabular}{|c|c|c|c|c|c|c|c|c|}
\hline No. & Questions & Mean & SD & 1 & 2 & 3 & 4 & $\begin{array}{c}\text { PC1 } \\
\text { loading }\end{array}$ \\
\hline 1 & $\begin{array}{l}\text { In your experience, to what extent is the park fulfilling its } \\
\text { role in combatting environmental deterioration? ( } 1 \text { not } \\
\text { doing enough, } 5 \text { doing a lot) }\end{array}$ & 3.7 & 1.0 & 3.7 & 3.9 & 3.2 & 3.9 & 0.13 \\
\hline 2 & $\begin{array}{l}\text { In your experience, to what extent do Parks contribute to } \\
\text { nature conservation? ( } 1 \text { not very much, } 5 \text { a lot) }\end{array}$ & 3.9 & 0.9 & 4.0 & 4.4 & 3.4 & 4.0 & 0.09 \\
\hline \multirow[t]{2}{*}{3} & $\begin{array}{l}\text { In your opinion, how much do tourists care about the } \\
\text { environment? ( } 1 \text { not very much, } 5 \text { a lot) }\end{array}$ & 3.7 & 0.8 & 3.6 & 3.5 & 3.7 & 3.9 & 0.11 \\
\hline & $\begin{array}{l}\text { In your opinion, what are the main reasons for tourists wan } \\
\text { a lot) }\end{array}$ & ng to visi & the $N$ & ation & 1 Park & ? $(1 \mathrm{n}$ & t ver & much, 5 \\
\hline 4 & Hiking and Trekking & 4.2 & 1.0 & 4.1 & 4.2 & 4.0 & 4.7 & 0.11 \\
\hline 5 & Picnicking & 3.2 & 1.2 & 3.1 & 3.4 & 3.3 & 3.0 & -0.03 \\
\hline 6 & Visit villages & 3.4 & 1.0 & 3.0 & 2.9 & 3.7 & 4.2 & 0.12 \\
\hline 7 & Recreational walking & 3.6 & 1 & 3.8 & 3.9 & 3.5 & 3.3 & 0.03 \\
\hline 8 & Wildlife photography & 3.2 & 1 & 3.2 & 3.5 & 2.9 & 3.4 & 0.08 \\
\hline 9 & Wildlife & 3.2 & 1.1 & 3.5 & 4.1 & 2.4 & 2.8 & 0.07 \\
\hline 10 & Visitor centres & 2.1 & 0.9 & 2.0 & 2.5 & 1.4 & 2.5 & 0.07 \\
\hline 11 & Horse riding excursions & 1.9 & 0.9 & 1.8 & 2.8 & 1.4 & 1.9 & 0.03 \\
\hline 12 & Other & 2.2 & 1.1 & 2.1 & 2.2 & 2.0 & 2.6 & 0 \\
\hline
\end{tabular}

In your opinion, which aspects do tourists consider most important in choosing a location? (1 not very important, 5 very important)

13 Accessibility

$\begin{array}{llllll}4 & 0.8 & 4.0 & 3.8 & 4.1 & 3.9\end{array}$

0.08

14 Information services

$\begin{array}{llllll}3.8 & 0.9 & 3.5 & 3.6 & 4.0 & 3.9\end{array}$

0.15

15 Friendliness of local residents

$\begin{array}{lllllll}4 & 0.8 & 3.9 & 4.1 & 4.0 & 4.2 & \mathbf{0 . 1 1}\end{array}$

16 Food quality and variety

$\begin{array}{llllll}4.1 & 0.7 & 4.1 & 4.0 & 4.1 & 4.3\end{array}$

0.04 


$\begin{array}{llllllllc}\mathbf{1 7} & \text { Landscape and nature } & 4.6 & 0.7 & 4.7 & 4.5 & 4.4 & 4.6 & \mathbf{0 . 1} \\ \mathbf{1 8} & \text { Cultural and artistic attractions } & 3.8 & 0.9 & 3.9 & 3.3 & 3.8 & 4.2 & \mathbf{0 . 1 4} \\ \mathbf{1 9} & \text { Environmental conservation } & 3.9 & 0.9 & 4.0 & 3.9 & 3.6 & 4.1 & \mathbf{0 . 1 4} \\ \mathbf{2 0} & \text { Efficiency of public services } & 3.3 & 1.1 & 3.5 & 3.4 & 3.0 & 3.5 & \mathbf{0 . 1 8} \\ \mathbf{2 1} & \text { Leisure activities and entertainment } & 3.1 & 1.1 & 2.8 & 3.2 & 3.0 & 3.3 & \mathbf{0 . 1} \\ \mathbf{2 2} & \text { Lack of pollution } & 3.8 & 1.1 & 3.8 & 3.9 & 3.7 & 3.7 & \mathbf{0 . 1 4}\end{array}$

How do tourists usually choose a tourist-hiking guide? (1 rarely, 5 frequently)

$\begin{array}{llccccccc}\mathbf{2 3} & \text { Specialized press } & 2.7 & 1.1 & 2.7 & 2.4 & 2.6 & 3.2 & \mathbf{0 . 1 5} \\ \mathbf{2 4} & \text { Tips from friends/family } & 4 & 0.9 & 4.4 & 3.7 & 3.9 & 3.9 & \mathbf{0 . 0 9} \\ \mathbf{2 5} & \text { Tourist information offices } & 3.3 & 1.0 & 3.5 & 3.1 & 3.0 & 3.7 & \mathbf{0 . 1 3} \\ \mathbf{2 6} & \text { Membership of specialized networks } & 3.6 & 1.0 & 3.5 & 3.5 & 3.7 & 3.6 & \mathbf{0 . 0 9} \\ \mathbf{2 7} & \text { Environmental certifications (Ecolabel, EMAS) } & 2.6 & 1.1 & 2.4 & 2.6 & 2.4 & 3.1 & \mathbf{0 . 1 5} \\ \mathbf{2 8} & \text { Internet } & 4.5 & 0.8 & 4.6 & 4.4 & 4.5 & 4.4 & \mathbf{0 . 0 8} \\ \mathbf{2 9} & \text { Associations } & 3.6 & 1.0 & 3.4 & 3.6 & 3.4 & 4.2 & 0.04\end{array}$

In your opinion, how important are the following factors in increasing sustainability for tourist staying in the park? (1 not very important, 5 very important)

40

41
Active planning

Visitors' environmental awareness

Staff training

Investment in water saving

Investment in energy saving

Investment in better waste management

Promotion of alternative mobility

Use local and organic food

Customer satisfaction questionnaires

Environmental quality certification

$\begin{array}{ccccccc}3.8 & 1 & 3.6 & 3.5 & 3.9 & 4.1 & \mathbf{0 . 1 5} \\ 4.1 & 0.9 & 4.2 & 4.0 & 4.1 & 4.0 & \mathbf{0 . 1 6} \\ 4.4 & 0.8 & 4.4 & 4.3 & 4.6 & 4.5 & \mathbf{0 . 1 3} \\ 3.4 & 0.9 & 3.4 & 3.5 & 3.3 & 3.4 & \mathbf{0 . 1 9} \\ 3.6 & 1.0 & 3.6 & 3.5 & 3.7 & 3.7 & \mathbf{0 . 2} \\ 3.9 & 0.9 & 4.1 & 3.7 & 3.8 & 4.0 & \mathbf{0 . 1 7} \\ 4 & 1.0 & 4.2 & 3.8 & 4.0 & 4.1 & \mathbf{0 . 1 5} \\ 4.4 & 0.7 & 4.4 & 4.1 & 4.6 & 4.6 & \mathbf{0 . 0 9} \\ 3 & 1.1 & 2.8 & 3.2 & 2.9 & 3.2 & \mathbf{0 . 1 7} \\ 3.3 & 1.2 & 2.9 & 3.3 & 3.3 & 3.8 & \mathbf{0 . 1 8}\end{array}$

In your opinion, how do tourists evaluate the territory with regard to the following factors? (1 not very important, 5 very important)

4 Water management

$\begin{array}{lllllll}2.9 & 0.9 & 3.2 & 2.6 & 2.9 & 2.9 & \mathbf{0 . 1 6}\end{array}$

Saving energy

Waste-disposal management

$\begin{array}{llllll}3 & 1.0 & 3.2 & 2.8 & 3.0 & 3.0\end{array}$

0.18

$\begin{array}{lllllll}3.6 & 1.2 & 3.6 & 3.2 & 3.5 & 4.2 & \mathbf{0 . 1 7}\end{array}$

Alternative mobility

$\begin{array}{llllll}3.4 & 1.3 & 3.6 & 3.4 & 3.1 & 3.6\end{array}$

0.16

In your opinion, how important is it for sustainability to have tourist structures certified according to environmental management standards? (1 not very important, 5 very

4

$\begin{array}{lllll}0.9 & 4.0 & 3.9 & 4.0 & 4.1\end{array}$

0.11 important) 
Give your opinion with respect to the main elements constituting the services offered to tourists (1 negative/unsatisfied, 5 positive/very satisfied)

\section{Accessibility}

Buildings (aesthetic/architectural aspects)

Professionalism/training of staff

Welcoming and reception system

Value for money

Quality of the accomodations (hotels)

Quality of services

Quality of the road network

Adequacy sustainable, slow mobility network (cycling routes and paths)

Can you give an opinion on the Park's contribution towards promoting natural heritage? Indicate how much on a scale from 1 to 5 ( 1 minimum level, 5 maximum level)

Does the Park promote sustainable tourism? (To what degree)

$\begin{array}{lllllll}2.9 & 1.1 & 3.0 & 2.6 & 2.7 & 3.2 & \mathbf{0 . 1 9} \\ 3.2 & 1.0 & 3.4 & 3.2 & 2.9 & 3.4 & \mathbf{0 . 1 4} \\ 3.7 & 1.0 & 3.4 & 3.3 & 3.9 & 4.1 & \mathbf{0 . 1 9} \\ 3.9 & 0.9 & 3.5 & 3.8 & 4.0 & 4.5 & \mathbf{0 . 1 7} \\ 3.8 & 0.9 & 3.5 & 3.5 & 4.1 & 4.1 & \mathbf{0 . 1 4} \\ 3.6 & 0.9 & 3.3 & 3.8 & 3.3 & 3.9 & \mathbf{0 . 1 5} \\ 3.6 & 0.9 & 3.4 & 3.3 & 3.7 & 3.7 & \mathbf{0 . 1 7} \\ 2.7 & 1.2 & 2.8 & 2.4 & 2.4 & 3.0 & \mathbf{0 . 1 7} \\ 3.1 & 1.3 & 3.7 & 2.8 & 2.4 & 3.6 & \mathbf{0 . 2 3} \\ & & & & & & \\ 3.2 & 1 & 3.2 & 3.4 & 2.5 & 3.8 & \mathbf{0 . 0 9} \\ & & & & & & \\ 3 & 0.9 & 3.3 & 2.9 & 2.2 & 3.5 & \mathbf{0 . 0 9}\end{array}$

Table A3 Original variables (questions) which exhibit the higher correlation with LD1; for each question, correlation and p-values are shown, together with the relative question number reported in Tab. A2.

\begin{tabular}{|c|c|c|c|}
\hline \multirow[t]{2}{*}{ Variable } & \multicolumn{2}{|c|}{ LD1 } & \multirow{2}{*}{$\frac{\text { Tab. A2 }}{\text { No. }}$} \\
\hline & cor. & p-value & \\
\hline $\begin{array}{l}\text { In your experience, to what extent do Parks contribute to nature } \\
\text { conservation? }\end{array}$ & -0.2773 & 0.016 & 2 \\
\hline $\begin{array}{l}\text { In your opinion, what are the main reasons for tourists wanting to } \\
\text { visit the National Park? (Wildlife) }\end{array}$ & -0.2855 & 0.013 & 9 \\
\hline $\begin{array}{l}\text { In your opinion, what are the main reasons for tourists wanting to } \\
\text { visit the National Park? (Visitor centres) }\end{array}$ & -0.3844 & 0.001 & 10 \\
\hline $\begin{array}{l}\text { In your opinion, what are the main reasons for tourists wanting to } \\
\text { visit the National Park? (Horse riding excursions) }\end{array}$ & -0.4629 & 0.000 & 11 \\
\hline $\begin{array}{l}\text { Give your opinion with respect to the main elements constituting } \\
\text { the services offered to tourists (Quality of the accomodations) }\end{array}$ & -0.2328 & 0.046 & 50 \\
\hline $\begin{array}{l}\text { How much does the park promotes its activities? Does the Park } \\
\text { promote sustainable tourism? (To what degree) }\end{array}$ & -0.3383 & 0.003 & 55 \\
\hline
\end{tabular}


Table A4 Original variables (questions) which exhibit the higher correlation with LD2; for each question, correlation and p-values are shown, together with the relative question number reported in Tab. A2.

\begin{tabular}{|c|c|c|c|}
\hline \multirow[t]{2}{*}{ Variable } & \multicolumn{2}{|c|}{ LD2 } & \multirow{2}{*}{$\begin{array}{c}\text { Tab. A2 } \\
\text { No. }\end{array}$} \\
\hline & cor. & p-value & \\
\hline $\begin{array}{l}\text { In your experience, to what extent is the park fulfilling its role in } \\
\text { combatting environmental deterioration? }\end{array}$ & 0.2380 & 0.041 & 1 \\
\hline $\begin{array}{l}\text { In your experience, to what extent do Parks contribute to nature } \\
\text { conservation? }\end{array}$ & 0.3903 & 0.001 & 2 \\
\hline $\begin{array}{l}\text { In your opinion, what are the main reasons for tourists wanting to } \\
\text { visit the National Park? (Visit villages) }\end{array}$ & -0.3270 & 0.004 & 6 \\
\hline $\begin{array}{l}\text { In your opinion, what are the main reasons for tourists wanting to } \\
\text { visit the National Park? (Recreational walking) }\end{array}$ & 0.2505 & 0.031 & 7 \\
\hline $\begin{array}{l}\text { In your opinion, what are the main reasons for tourists wanting to } \\
\text { visit the National Park? (Wildlife) }\end{array}$ & 0.4928 & 0.000 & 9 \\
\hline $\begin{array}{l}\text { In your opinion, what are the main reasons for tourists wanting to } \\
\text { visit the National Park? (Visitor centres) }\end{array}$ & 0.2515 & 0.030 & 10 \\
\hline $\begin{array}{l}\text { In your opinion, what are the main reasons for tourists wanting to } \\
\text { visit the National Park? (Horse riding excursions) }\end{array}$ & 0.2343 & 0.044 & 11 \\
\hline $\begin{array}{l}\text { Give your opinion with respect to the main elements constituting } \\
\text { the services offered to tourists (Welcoming and reception system) }\end{array}$ & -0.2657 & 0.022 & 48 \\
\hline $\begin{array}{l}\text { Give your opinion with respect to the main elements constituting } \\
\text { the services offered to tourists (Value for money) }\end{array}$ & -0.2773 & 0.016 & 49 \\
\hline $\begin{array}{l}\text { How much does the park promotes its activities? Does the Park } \\
\text { promote sustainable tourism? (To what degree) }\end{array}$ & 0.2815 & 0.015 & 55 \\
\hline
\end{tabular}

Table A5 Original variables (questions) which exhibit the higher correlation with LD3; for each question, correlation and p-values are shown, together with the relative question number reported in Tab. A2.

\begin{tabular}{lccc}
\hline \hline Variable & & LD3 & Tab. A2 \\
\hline & cor. & p-value & No. \\
In your opinion, what are the main reasons for tourists wanting to & 0.2489 & 0.032 & 4 \\
visit the National Park? (Hiking and Trekking) & & &
\end{tabular}


In your opinion, what are the main reasons for tourists wanting to visit the National Park? (Picnicking)

In your opinion, what are the main reasons for tourists wanting to visit the National Park? (Wildlife)

In your opinion, which aspects do tourists consider most important in choosing a location? (Cultural and artistic attractions)

How do tourists usually choose a tourist-hiking guide? (Tourist information offices)

How do tourists usually choose a tourist-hiking guide? (Associations)

$$
-0.2948
$$

0.010

In your opinion, how do tourists evaluate the territory with regard to the following factors? (Waste-disposal management)

$-0.3293$

0.004

Give your opinion with respect to the main elements constituting the services offered to tourists (Adequacy sustainable, slow mobility network unsatisfied)

Can you give an opinion on the Park's contribution towards promoting natural heritage? Indicate how much on a scale from 1 to 5

How much does the park promotes its activities? Does the Park promote sustainable tourism? (To what degree)

Table A6 Sex ratio and age metrics of the surveyed hiking guides

\begin{tabular}{ccccccc}
\hline \hline National Park & Male \% & Female \% & Max age & Min age & Mean age & DS age \\
\hline FCNP & 57 & 43 & 71 & 32 & 46 & \pm 10.3 \\
ALNP & 53 & 47 & 68 & 29 & 50 & \pm 8.2 \\
PNP & 86 & 14 & 58 & 31 & 49 & \pm 8.7 \\
ANP & 84 & 16 & 62 & 33 & 42 & \pm 7.8 \\
\hline
\end{tabular}

